\title{
THỰC TRẠNG PHÁ THAI LẶP LẠI TRONG NHÓM PHỤ NỮ ĐẾN PHÁ THAI TẠI BỆNH VIỆN PHỤ SẢN HÀ NỘI NĂM 2020
}

\author{
Nguyễn Thị Thúy Hạnh ${ }^{1}$, Trần Thị Thảo Anh ${ }^{1}$, \\ Bui Kim Chi ${ }^{2}$, Trần Tho $\mathrm{Nhị}^{1}$
}

\section{TÓM TẮT}

Phá thai lặp lại ở Việt Nam cũng như nhiều nước trên thế giới còn rất phổ biến mă̆c dù tiềm ẩn nhiều nguy cơ ảnh hưởng không chỉ đến sức khỏe về thể chất mà còn đến sức khỏe tâm thần. Nghiên cứu được tiến hành ở bệnh viện Phụ sản Hà Nội nhằm mô tả thực trạng phá thai lặp lại và một số yếu tố liên quan ở nhóm phư nữ tới phá thai. Nghiên cứ đã sử dụng phương pháp mô tả cắt ngang phỏng vấn trực tiếp trên 477 phư nữ đến phá thai cho kết quả: tỷ lệ phá thai lăp lai là 22,2\%. Các yếu tố liên quan bao gồm: nghề nghiệp, tuổi càng cao càng có nguy cơ phá thai lăp laai cao. Các yếu tố về gia đình và xã hội như có đủ 2 con trở lên, có con trai, việc sử dụng bao cao su, chồng/người yêu là người có ảnh hưởng nhất đến quyết định phá thai và mong muốn tiếp tục có thai trong tương lai có liên quan đến tình trang phá thai lặp laai. Hơn một phần năm số phụ nữ phá thai lặp lại và có mối liên quan đến yếu tố gia đình và xã hội. V̀̀ vậy, cần có các phương pháp can thiệp thích hợp để làm giảm tỷ lệ phá thai lặp lại. quan.

Tư khóa: Phá thai, phá thai lặp lại, các yếu tố liên

\section{SUMMARY \\ SITTUATION OF REPEAT ABORTION AMONG WOMEN HAVING ABORTION IN HANOI OBSTETRICS AND GYNECOLOGY HOSPITAL, 2020}

Repeat abortion in Vietnam as well as many countries around the world is still very popular despite the potential risks affecting not only physical health but also mental health. It was conducted at Hanoi Obstetrics and Gynecology Hospital to describe the situation of repeat abortions and some associated factors among women having abortion. It used a descriptive cross-sectional method to interview 477 women to have an abortion with the results: the repeat abortion rate was $22.2 \%$. Associated factors include: occupation, the older you are, the higher the risk of repeat abortions. Family and social factors such as having 2 or more children, having a son, using condoms, husband/partner have the most influence on abortion decision and desire to continue Future pregnancies are associated with repeat abortions. More than one-fifth of women have repeat abortions and are related to family and social factors. Therefore,

\section{${ }^{1}$ Trường Đại học Y Hà Nội}

${ }^{2}$ Học viện Hành chính Quốc gia

Chịu trách nhiệm chính: Nguyễn Thị Thúy Hạnh

Email: nguyenthithuyhanh@hmu.edu.vn

Ngày nhận bài: 25.10.2021

Ngày phản biện khoa học: 20.12.2021

Ngày duyệt bài: 30.12.2021 appropriate interventions are needed to reduce repeat abortion rate.

Key word: abortion, repeat abortion, Associated factors.

\section{I. ĐăT VẤN ĐỀ}

Ở Việt Nam nói riêng cũng như nhiều nước trên thế giới nói chung, phá thai và phá thai lặp lại còn phổ biến. Theo tổ chức $Y$ tế Thế giới (WHO), hằng năm, hơn một nửa số ca mang thai - 121 triệu - là ngoài ý muốn. Viện Guttmacher cho biết, trong giai đoạn từ năm 2010-2014, trên toàn thế giới có $56 \%$ số ca mang thai ngoài ý muốn kết thúc bằng việc phá thai [1]. Việt Nam xếp hạng là một trong 5 quốc gia có tỷ lệ phá thai cao nhất trên thế giới và đứng đâu Đông Nam Á (WHO). Năm 2018, theo báo cáo kết quả nghiên cứu Đánh giá chất lượng Kế hoạch hóa gia đình Việt Nam, tổng tỷ suất phá thai ở Việt Nam là 0,42 , nghĩa là cứ 5 phụ nữ thì có 2 người đã từng phá thai ít nhất một lần trong toàn bộ giai đoạn sinh sản. Mặc dù hiện nay đã có nhiều phương pháp phá thai tương đối an toàn, tuy nhiên phá thai lặp lại vẫn tiêm ẩn nhiêu nguy cơ ảnh hưởng xấu không chỉ đến sức khỏe về thể chất, khả năng tiếp tục mang thai của người phụ nữ, mà còn về tính mạng, về vấn đề sức khỏe tâm thân. Phá thai dù là với bất kỳ lý do nào thì hậu quả của việc phá thai lặp lại sẽ ảnh hưởng lớn đến tâm lý của người phụ nữ như stress nặng nề, rối loạn tinh thân, suy sụp, sợ hãi, tự dằn vặt bản thân [2].

Ở Việt Nam cũng như trên thế giới, phân lớn các nghiên cứu về phá thai lặp lại được thực hiện tại các bệnh viện lớn và đã làm cách nay khá lâu. Để có những số liệu thực tế, mới nhất và hiểu được các yếu tố liên quan đến việc người phụ nữ nguy cơ cao hoăc quyết định phá thai lặp lại, từ đó đưa ra những đề xuất can thiệp cân thiết để làm giảm tỷ lệ các trường hợp phá thai lặp lại, chúng tôi đã thực hiên đề tài nghiên cứu: "Thực trang phá thai lặp lại trong nhóm phụ nữ đến phá thai tại bệnh viện Phụ sản Hà Nội năm 2020" với mục tiêu: Mô tả thực trạng phá thai lặp lại ở nhóm phu nữ tới phá thai tai Bệnh viên Phu sản Hà Nội năm 2020 và phân tích một số yếu tố liên quan đến việc phá thai lặp lại ở nhóm phụ nữ tới phá thai tại Bệnh viện Phụ sản Hà Nội năm 2020. 
II. ĐỐI TƯỢNG VÀ PHƯƠNG PHÁP NGHIÊN CỨU

1. Đối tượng. Những phụ nữ đến phá thai tại khoa Kế hoạch hóa gia đình, bệnh viện Phụ sản Hà Nội.

Tiêu chuân lưa chon: (1) Phu nữ đễn phá thai tại khoa Kế hoạch hóa gia đình, bệnh viện Phụ sản Hà Nội. (2) Được chẩn đoán có thai, và có giấy chỉ định làm thủ thuật phá thai. (3) Đồng ý trả lời phỏng vấn.

Tiêu chuẩn loại trừ: (1) Phụ nữ không có khả năng trả lời câu hỏi phỏng vẩn (do quá mệt hoặc có vấn đề về tâm thần...). (2) Các đối tượng từ chối tham gia nghiên cứu.

\section{Phương pháp}

Thiết kế nghiên cứu: nghiên cứu mô tả cắt ngang.

Thời gian nghiên cứu: từ tháng 01/2020 đến tháng $5 / 2021$.

Thời gian thu thập số liệu: từ tháng 04/2020 đến tháng 12/2020.

Địa điểm: nghiên cứu được tiến hành tại Bệnh viện Phu sản Hà Nội.

Cõ mẫu và phương pháp chọn mẫu: Áp dụng tính cõ̃ mẫu cho áp dụng 1 tỳ lệ trong nghiên cứu cắt ngang, với độ tin cậy là $95 \%$, sai số $\varepsilon=$ 0,15 và $p=0,317$ là tỷ lệ phu nữ phá thai lặp lại. Tỷ lệ $\mathrm{p}$ được lấy từ một nghiên cứu về phá thai lặp lại ở phụ nữ trong 62 cơ sở y tế công lập ở Hà Nội, Khánh Hòa và Thành phố Hồ Chí Minh của 1224 đối tượng vào năm 2014, tính ra cõ mẫu tối thiểu cần thu thập là 368 đối tượng. Cõ mẫu thực tế để phân tích số liệu cho nghiên cứu này là lấy toàn bộ phụ nữ đến phá thai tại khoa Kế hoạch hóa gia đình, bệnh viện Phụ sản Hà Nội năm 2020 với tổng số phụ nữ là 515 phụ nữ. Tuy nhiên sau khi làm sạch số liệu (loại bó các giá trị missing) thì cỡ mẫu để phân tích số liệu trong nghiên cứu này là 477 phụ nữ.

Kỹ thuật và công cụ thu thập số liệu: Thu thập thông tin qua phỏng vấn cá nhân trực tiếp bằng bộ câu hỏi về các phần thông tin chung, câu hỏi liên quan đến tiền sử sinh sản và một số yếu tố liên quan.

3. Xử lý số liệu. Số liệu được nhập bằng KoboToolbox và được quản lý, phân tích bằng phần mềm STATA 14.0. Sử dụng trung bình và tỷ lệ để mô tả biến số nghiên cứu. Phân tích hồi quy đơn biến để xác định một số yếu tố liên quan đến phá thai lặp lại.

\section{KẾT QUẢ NGHIÊN CỨU}

Tuổi trung bình của đối tượng nghiên cứu là 26,1 tuổi. Hơn $70 \%$ là độ tuổi từ 21-29 tuổi. Khoảng gần $20 \%$ từ 30 tuổi trở lên và $9,2 \%$ là từ 18-20 tuổi. Hơn $70 \%$ người được hỏi có trình độ học vấn từ đại học/cao đẳng/trung cấp trở lên. Hơn một nửa nhóm đối tượng là chưa kết hôn (57,2\%), đối tượng đã kết hôn chiếm 42,8\%. Đa số các đối tượng là chưa có con chiếm $79,6 \%$. Có 56 đối tượng đang có con trai chiếm 11,7\% và 60 đối tượng đang có con gái chiếm 12,6\%.

3.1 Tỷ lệ phá thai lặp lại. Biểu đồ 1 cho thấy có 106 đối tượng (chiếm 22,2\%) phá thai lặp lại trong tổng số 477 phụ nữ đến phá thai Thực trạng phá thai lặp lại

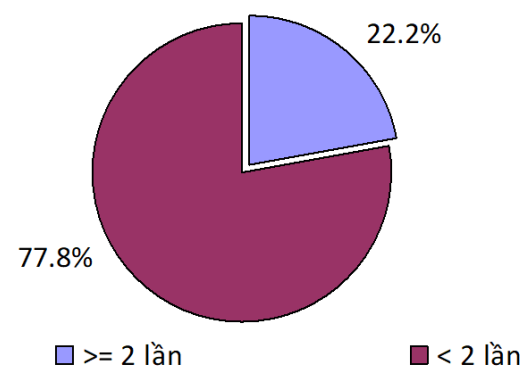

Biểu đồ 1. Tỉ lệ phụ nữ phá thai lặp lại

Tỷ lệ phá thai lặp lại

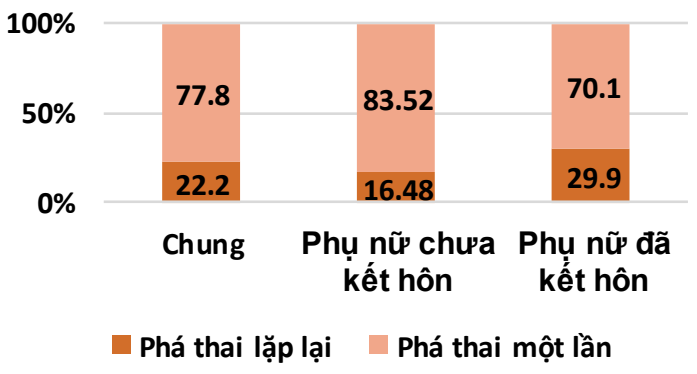

\section{Biểu đồ 2. Tỉ lệ kêt hôn ở nhóm phụ nữ đã} kêt hôn và chưa kêt hôn

Biểu đồ 2 cho thấy tỷ lệ phá thai lặp lại ở nhóm phụ nữ đã kết hôn cao hơn so với nhóm phụ nữ chưa kết hôn.

\subsection{Mối liên quan giữa một số yếu tố và phá thai lặp lại}

Bảng 1. Một số yêu tố về nhân khâu học của phụ nữ liên quan đến phá thai lặp lại

\begin{tabular}{|c|c|c|c|c|}
\hline Yếu tố & $\begin{array}{c}\text { Phá thai lặp } \\
\text { lại }(\mathbf{2}) \mathbf{n}(\mathbf{\%})\end{array}$ & $\begin{array}{c}\text { Phá thai một } \\
\text { lân } \mathbf{n}(\mathbf{\%})\end{array}$ & OR (95\% CI) & Giá trị p \\
\hline Tuối: & $53(14,2)$ & $321(85,8)$ & 1 & \\
\hline$\geq 30$ & $43(46,2)$ & $50(53,8)$ & $5,21(3,16-8,59)$ & $<0,0001$ \\
\hline
\end{tabular}


VIETNAM MEDICAL JOURNAL N01 - JANUARY - 2022

\begin{tabular}{|c|c|c|c|c|}
\hline \multicolumn{5}{|l|}{ Nghề nghiệp } \\
\hline Học sinh/sinh viên & $8(7,5)$ & $99(92,5)$ & 1 & \\
\hline $\begin{array}{l}\text { Nông dân/nội trợ/thất } \\
\text { nghiệp/công nhân }\end{array}$ & $10(25,0)$ & $(75,0)$ & $4,12(1,49-11,39)$ & $<0,0001$ \\
\hline $\begin{array}{l}\text { Cán bộ viên chức/nhân viên } \\
\text { công ty/tổ chức tư nhân }\end{array}$ & $41(23,4)$ & $134(76,6)$ & $3,79(1,69-8,43)$ & 0,0062 \\
\hline Tự do & $47(30,3)$ & $108(69,7)$ & $5,38(2,43-11,95)$ & $<0,0001$ \\
\hline \multicolumn{5}{|l|}{ Tình trạng hôn nhân } \\
\hline Chưa kết hôn & $143(38,5)$ & $228(61,5)$ & 1 & \\
\hline Đã kết hôn & $61(57,5)$ & $45(42,5)$ & $2,22(1,43-3,45)$ & 0,0006 \\
\hline
\end{tabular}

Bảng 1 cho kết quả phân tích đơn biến như nhân viên công ty/tổ chức tư nhân và tự do có sau: nhóm phụ nữ tuổi từ 30 trở lên có khả khả năng phá thai lặp lại cao hơn lần lượt 4,12; năng phá thai lặp lại lần lượt cao hơn 5 lần so với độ tuổi thấp hơn, sự khác biệt này có ý nghĩa thống kê với $(p<0,05)$.

Về nghề nghiệp, những phụ nữ làm nghề nội trợ/thất nghiệp; công nhân; cán bộ viên chức;

3,79 và 5,38 so với nhóm học sinh/sinh viên.

Nhóm đã kết hôn có khả năng phá thai lặp lại cao hơn 2,22 lần so với nhóm chưa kết hôn, sự khác biệt này có ý nghĩa thống kê với $(p<0,05)$.

Bảng 2. Một số yêu tố về gia đình và xã hội liên quan đến tình trạng phá thai lặp lại của phun nữ

\begin{tabular}{|c|c|c|c|c|}
\hline Yếu tố & $\begin{array}{l}\text { Phá thai lặp lại } \\
(\geq 2) \text { n }(\%)\end{array}$ & $\begin{array}{l}\text { Phá thai một } \\
\text { lân n (\%) }\end{array}$ & OR (95\% CI) & $\begin{array}{c}\text { Giá trị } \\
\text { P }\end{array}$ \\
\hline \multicolumn{5}{|c|}{ Số con sống hiện tại } \\
\hline 0 & $65(17,1)$ & $315(82,9)$ & 1 & \\
\hline 1 & $11(31,4)$ & $24(68,6)$ & $2,22(1,04-4,76)$ & 0,04 \\
\hline 2 & $22(45,8)$ & $26(54,2)$ & $4,10(2,19-7,68)$ & $<0,0001$ \\
\hline$>=3$ & $8(57,1)$ & $6(42,9)$ & $6,46(2,17-19,25)$ & 0,0008 \\
\hline \multicolumn{5}{|c|}{ Số con trai, con gái hiên taì } \\
\hline Chưa có con & $66(17,3)$ & $315(82,7)$ & 1 & \\
\hline Chỉ có con gái & $18(45,0)$ & $22(55,0)$ & $3,91(1,98-7,69)$ & 0,0008 \\
\hline Có cả con trai, con gái & $12(33,3)$ & $24(66,7)$ & $2,39(1,14-5,01)$ & 0,0216 \\
\hline Chỉ có con trai & $10(58,8)$ & $7(41,2)$ & $6,82(2,50-18,56)$ & 0,0002 \\
\hline \multicolumn{5}{|c|}{ Sứ dụng bao cao su } \\
\hline Không & $80(25,6)$ & $232(74,4)$ & $6,46(2,17-19,25$ & 0,0008 \\
\hline Có & $26(15,8)$ & $139(84,2)$ & 1 & \\
\hline \multicolumn{5}{|c|}{ Sữ dụng biện pháp tránh thai } \\
\hline Có & $38(21,2)$ & $141(78,8)$ & 1 & \\
\hline Không & $68(22,8)$ & $230(77,2)$ & $1,84(1,13-3,01)$ & 0,0144 \\
\hline \multicolumn{5}{|c|}{ Người có ảnh hưởng nhất đến quyết định phá thai } \\
\hline Bản thân & $62(20,5)$ & $240(79,5)$ & 1 & \\
\hline Chồng (người yêu) & $26(33,8)$ & $51(66,2)$ & $1,97(1,14-3,42)$ & 0,0152 \\
\hline Gia đình/bác sĩ & $17(18,3)$ & $76(81,7)$ & $0,86(0,48-1,57)$ & 0,6354 \\
\hline \multicolumn{5}{|c|}{ Mong muốn tiếp tục mang thai } \\
\hline Không & $20(37,0)$ & $34(63,0)$ & $2,30(1,26-4,20)$ & 0,0065 \\
\hline Có & $86(20,3)$ & $337(79,7)$ & 1 & \\
\hline
\end{tabular}

*Cho con bú vô kinh, Màng phim tránh thai...

Bảng 2 cho thấy: những phụ nữ có nhiều con thì khả năng phá thai lặp lại càng cao từ 2,22 đến 6,46 so với những phụ nữ không có con, sự khác biệt này có ý nghĩa thống kê với $(p<0,05)$. Những phụ nữ chỉ có con trai hoặc chỉ có con gái hoặc có cả con trai và con gái thì khả năng phá thai lặp lại cao hơn từ 2,39 đến 6,82 lầ so với những phụ nữ chưa có con, sự khác biệt này có ý nghĩa thống kê với $(p<0,05)$.

Những phụ nữ có chồng quyết định đến phá thai thì khả năng phá thai lặp lại ở phụ nữ cao hơn gần 2 lần so với bản thân phụ nữ quyết định, sự khác biệt này có ý nghĩa thống kê với $(p<0,05)$.

Việc sử dụng các BPTT cũng có mối liên quan đến tỷ lệ phá thai lặp lại. Cụ thể, các đối tượng 
không sử dụng bao cao su tránh thai có khả năng phá thai lặp lại cao hơn 6 lần so với những đối tượng có sử dụng, sự khác biệt này có ý nghĩa thống kê với $(p<0,05)$.

Những phụ nữ không mong muốn có con thì khả năng phá thai lặp lại cao hơn 2 lần so với những phụ nữ muốn có con trong tương lai, sự khác biệt này có ý nghĩa thống kê với $(p<0,05)$.

\section{BÀN LUÂ̂N}

Nghiên cứu đã tiến hành trên 477 người tham gia là phụ nữ đến phá thai tại bệnh viện Phụ sản Hà Nội cho thấy khoảng hơn một phần năm phụ nữ phá thai lặp lại $(22,2 \%)$. Con số này cao hơn con số được tìm thấy trong một số nghiên cứu trước tại Việt Nam về phá thai lặp lại [3]' [4], nhưng lại thấp hơn so với các nghiên cứu có cùng thiết kế ở các nước phương Tây [5]' [6].

Những người trong độ tuổi từ 30-34 có nguy cơ phá thai lặp lại cao hơn so với những người trong độ tuổi từ 30 tuổi trở lên, đặc biệt là những người từ 35 tuổi trở lên. Điều này dễ hiểu là vì phụ nữ sinh con muộn tiềm ẩn rất nhiều nguy cơ. Từ 30 tuổi trở lên, phụ nữ thường đã có đủ số con và bắt đầu xuất hiện các vấn đề sức khoẻ bệnh tật tăng lên cho cả me và con, đặc biệt khi phụ nữ ngoài 35 tuổi. Nên đó có thể là lý do làm gia tăng tỷ lệ phá thai lặp lại.

Nếu nghiên cứu trước ở Việt Nam cho thây không có sự liên quan về yếu tố nghề nghiệp đến phá thai lặp lại, thì nghiên cứu của chúng tôi lại cho thấy điều ngược lại. Cụ thể trong nghiên cứu của chúng tôi nhóm nội trợ/thất nghiệp, công nhân, cán bộ viên chức, nhân viên công ty tư nhân và tự do có nguy cơ phá thai lặp lại cao hơn so với nhóm học sinh/sinh viên. Điều này được giải thích là do ở 5 nhóm đối tượng này kiến thức về sức khỏe sinh sản, tình dục còn thấp. Nhóm người này không có kiến thức về phòng tránh thai và có tỷ lệ phá thai cao nhất. Nhóm cán bô viên chức có thể do tính chất công việc không cho phép. Pháp lệnh dân số ở Việt Nam quy định: viên chức, công chức làm trong cơ quan nhà nước sinh con thứ ba trở lên trừ những trường hợp đặc biệt sẽ bị xử lý và kỷ luật. Vì vậy tỷ lệ phá thai lặp lại ở 5 nhóm đối tượng trên tăng cao là điều dể hiểu.

Những phụ nữ đang có từ 2 con trở lên có nguy cơ phá thai lặp lại cao hơn so với những đối tượng đang không có con sống ở hiện tại. Điều này có thể giải thích là do Việt Nam áp dụng chính sách kế hoạch hóa gia đình. Hay do tính chất công việc không cho phép là một trong những lý do phá thai có mối liên quan đến tỷ lệ phá thai lặp lại. Người phụ nữ đã có đủ 2 con trở lên cũng dể hiểu khi không có nhu cầu sinh thêm con, có xu hướng chấm dứt thai kỳ bằng phá thai hơn là giữ lại nhằm hạn chế số con, do vậy nguy cơ phá thai lặp lại cũng từ đó mà tăng lên theo.

Các nghiên cứu trước đây đã cho thấy mối tương quan giữa sở thích có con trai ở Việt Nam, tỷ lệ nạo phá thai cao và mất cân bằng giới tính khi sinh [7], [8]. Nghiên cứu của chúng tôi ở hiện tại cũng có nét tương đồng, cụ thể: những phụ nữ có từ 2-5 con trai thì nguy cơ phá thai lặp lại cao hơn hẳn, cao hơn 6,8 lần so với những phụ nữ có 0 con trai. Điều này cho thấy rằng, hiện nay khi bình đẳng giới đang dần được thiết lập, vị thế của người phụ nữ/con gái dần được khẳng định, tuy nhiên sự ưa thích con trai vẫn không hề giảm.

Những đối tượng sử dụng bao cao su tránh thai có nguy cơ phá thai lặp lại thấp hơn so với những đối tượng không sử dụng. Thực tế cho thấy rằng, việc sử dụng bao cao su thực sự đem lại hiệu quả cao trong việc giảm tỷ lệ phá thai lặp lại. Không chỉ vậy, bao cao su còn rất tiện lợi và dễ sử dụng, hiện nay việc mua bao cao su dễ dàng hơn nhiêu so với trước đây khi các cửa hàng tiện lợi phục vụ 24/24, bao cao su không những hiệu quả mà còn là một biện pháp hữu hiệu để bảo vệ bản thân và bạn tình trong việc phòng tránh các bệnh lây truyền qua đường tình dục.

Người có ảnh hưởng nhất đến việc phá thai có mối tương quan đến hành vi phá thai lại là người chồng/người yêu với tỷ lệ phá thai lặp lại là $33,8 \%$ có nguy cơ cao hơn 2,2 lần so với chính bản thân người phụ nữ đưa ra quyết định phá thai. Việc phụ thuộc vào kinh tế vào chồng/người yêu, hay việc bạn gái mang thai mà không được bạn trai chẩp nhận cái thai dẫn đến gia đình bị ảnh hưởng vì mọi xung quanh dị nghị, bản thân người con gái cũng sẽ bị dị nghị, cái dị nghị đó sẽ thành áp lực vô cùng lớn. Việc phá bỏ cái thai cũng là điêu dễ hiểu, kéo theo đó góp phần gia tăng tình trạng phá thai lặp lại.

\section{KẾT LUẬN}

Tỷ lệ phá thai lặp lại ở nhóm phụ nữ đến phá thai tại bệnh viện Phụ sản Hà Nội là khá cao, chiếm tỷ lệ $22,2 \%$. Tình trạng phá thai lặp lại cao nhất ở nhóm tuổi từ 30 tuổi trở lên, đạ̣c biệt là nhóm tuổi trên 35 với 54,5\%. Nhóm cán bộ viên chức có tỉ lệ phá thai lặp lại cao nhất trong nhóm nghề nghiệp với 32,4\%. Những phụ nữ tuổi từ 30 tuổi trở lên; nghề nghiệp là công nhân, cán bộ viên chức, nội trợ/thất nghiệp, nhân viên công ty tư nhân, làm tự do; phụ nữ từ có từ 2 con hiện tại trở lên; có con trai; sử dụng 
bao cao su tránh thai; mong muốn có thai trong tương lai và người ảnh hưởng nhất đến quyết định phá thai là người chồng/người yêu là những yếu tố có mối liên quan có ý nghĩa thống kê đễn phá thai lặp lại của đối tượng nghiên cứu $(p<0,05)$.

\section{TÀI LIÊU THAM KHẢO}

1. Singh S., Remez L., Sedgh G. và cộng sự. (2018). Abortion Worldwide 2017: Uneven Progress and Unequal Access. .

2. Mota N.P., Burnett M., và Sareen J. (2010). Associations between abortion, mental disorders, and suicidal behaviour in a nationally representative sample, Can J Psychiatry, 55(4), 239-247.

3. Nguyển Hữu Thời N.T.T.V. Tỷ lệ và các yễu tỗ liên quan đến phá thai lặp lại ở phụ nữ trong tuổi sinh đẻ có chông tại xầ Nhơn Ai, huyện Phong Điên, thành phố Cần Tho. <https:// yhoctphcm.ump.edu.vn/index.php? Content= ChiTietBai\&idBai=6869>, accessed: 09/12/2021.

4. Vương L.H. và Thương B.C. (2018). Tỷ lệ và các yếu tố liên quan đến phá thai lặp lại ở nhửng phụ nữ tới phá thai tại bệnh viện đa khoa tỉnh đồng nai. 7.

5. Picavet C., Goenee M., và Wijsen C. (2013). Characteristics of women who have repeat abortions in the Netherlands. The European Journal of Contraception \& Reproductive Health Care, 18(5), 327-334.

6. Toprani A. (2015). Repeat Abortions in New York City, 2010. J Urban Health, 92(3), 593-603.

7. Chatterjee P. (2009). Sex ratio imbalance worsens in Vietnam. The Lancet, 374(9699), 1410.

8. Ngo T.D., Keogh S., Nguyen T.H. và cộng sự. (2014). Risk factors for repeat abortion and implications for addressing unintended pregnancy in Vietnam. International Journal of Gynecology \& Obstetrics, 125(3), 241-246.

\section{NGHIÊN CỨU TỔNG QUAN VỀ MỐI LIÊN QUAN GIỮA GEN VÀ CÁC BÊ̂NH CHUYỂN HÓA TRÊN CO' SỞ XÉT NGHIỆM GEN CircleDNA}

\section{Trương Hồng Sơn*, Nguyễn Xuân Ninh*, Lưu Liên Hương*, Lê Minh Khánh*}

\section{TÓM TẮT}

Gen và các bệnh chuyển hóa là một nhánh của xét nghiệm gen, nhẳm xác định vai trò của các biến thể gen đặc hiệu với các vấn đề liên quan đến chuyển hóa ví dụ như khả năng điều hòa đáp ứng với các thành phần của chế độ ăn, các kết quả của tương tác gen với chế độ ăn đển tình trạng sức khỏe và đặc biệt là khả năng mắc các bệnh liên quan đến chuyển hóa. Các nghiên cứu về Gen và các bệnh chuyển hóa trong lâm sàng đã cho thấy: (1) Các gen được chứng minh là có liên quan khá mạnh đến bệnh tiểu đường type 2 là TCF7L2, tiểu đường typ 1 là SLC30A8, (2) Các gen đã được chứng minh là có liên quan đến tất cả các chỉ số đánh giá rối loạn lipid máu, bao gồm cholesterol toàn phân, $L D L, H D L$ và triglyceride là $P C S K 9$ và $L D L R$, (3) Một số đa hình của gen FTO có thể làm tăng nguy cơ thừa cân béo phì trên nhiều đối tượng như người trưởng thành, trẻ em...Gen BDNF có ảnh hưởng đến quá trình điêu hoà cân bằng năng lượng, cũng như các cảm giác thèm ăn và các rối loạn về thần kinh liên quan, (4) Gen đã được chứng minh có liên quan đến các dạng ung thư thường gặp bao gồm gen $\mathrm{MSH} 2$ với ung thư đại trực tràng, BRCA1, BRCA2 với ung thư vú.

Tư khóa: bệnh chuyển hóa, rối loạn chuyển hóa, gen và chuyển hóa

*Viện Y học ứng dụng Việt Nam

Chịu trách nhiệm chính: Trương Hồng Sơn

Email: vienyhocungdung@gmail.com

Ngày nhận bài: 26.10.2021

Ngày phản biện khoa học: 27.12.2021

Ngày duyệt bài: 4.01.2022

\section{SUMMARY}

\section{REVIEW ABOUT THE ASSOCIATION} BETWEEN GENES AND METABOLIC

\section{DISEASES BASED ON CircleDNA TEST}

Genes and metabolic syndromes is a branch of genomic testing, to determine the role of specific gene variants with metabolism-related characteristics, including the responses to diet, and the interactions between genes and diet on health status and the risk of metabolic diseases. Studies about genes and metabolism have shown that: 1) Genes that have been shown to be strongly associated with type 2 diabetes is TCF7L2, type 1 diabetes is SLC30A8, (2) The genes have been shown to be associated with all markers of dyslipidemia, including total cholesterol, $\mathrm{LDL}, \mathrm{HDL}$, and cholesterol, triglycerides are PCSK9 and LDLR, (3) Some polymorphisms of the FTO gene can increase the risk of overweight and obesity in many subjects such as adults, children... BDNF gene affects the regulation of homeostasis. energy, as well as cravings and related neurological disturbances, (4) Genes that have been shown to be associated with common cancers include $\mathrm{MSH} 2$ gene for colorectal cancer, BRCA1, BRCA2 for breast cancer

Keyword: metabolic disease, metabolic disorders, genes, metabolism

\section{I. ĐẶT VẤN ĐỀ}

Giải mã gen là một trong những bước đột phá của nền y học hiện đại. Tính ưu việt của phương pháp giải mã gen được ứng dụng nhiều nhất trong chẩn đoán và điều trị bệnh. Giải mã gen 